\title{
Longitudinal Small-Animal PET Imaging of the zQ175 Mouse Model of Huntington Disease Shows In Vivo Changes of Molecular Targets in the Striatum and Cerebral Cortex
}

\author{
Jenny Häggkvist ${ }^{1}$, Miklós Tóth ${ }^{1}$, Lenke Tari ${ }^{1}$, Katarina Varnäs ${ }^{1}$, Marie Svedberg ${ }^{1}$, Anton Forsberg ${ }^{1}$, Sangram Nag ${ }^{1}$, \\ Celia Dominguez ${ }^{2}$, Ignacio Munoz-Sanjuan ${ }^{2}$, Jonathan Bard ${ }^{2}$, John Wityak ${ }^{2}$, Andrea Varrone ${ }^{1}$, Christer Halldin ${ }^{1}$, \\ and Ladislav Mrzljak ${ }^{2}$
}

${ }^{1}$ Department of Clinical Neuroscience, Karolinska Institutet, Stockholm, Sweden; and ${ }^{2}$ CHDI Management/CHDI Foundation, Princeton, New Jersey

Since the discovery of the HTT gene in 1993, numerous animal models have been developed to study the progression of Huntington disease (HD) and to evaluate potential new therapeutics. In the present study, we used small-animal PET to characterize the expression of molecular targets in the recently reported HD animal model, the zQ175 mouse model. Methods: Male heterozygous zQ175 ( $\mathrm{Htt} \mathrm{t}^{\mathrm{tm} 1 \mathrm{Mfc}} / 190 J C h d i$, CHDI-81003003) and wild-type (WT, C57BL/6J) animals were imaged with the dopamine $D_{2}$ receptor radioligand ${ }^{11} \mathrm{C}$-raclopride, the PDE10A radioligand ${ }^{18} \mathrm{~F}-\mathrm{MNI}-659$, the dopamine $\mathrm{D}_{1}$ receptor radioligand ${ }^{11} \mathrm{C}$ $\mathrm{NNC} 112$, and the $5-\mathrm{HT}_{2 \mathrm{~A}}$ radioligand ${ }^{11} \mathrm{C}-\mathrm{MDL} 100907$ at 6 and $9 \mathrm{mo}$ of age. The outcome measure was the binding potential $\left(B P_{\mathrm{ND}}\right)$, using the cerebellum as the reference region. Selected regions of interest were the striatum for all radioligands and additionally the striatum, rostral cortex, caudal cortex, and hippocampus for ${ }^{11} \mathrm{C}-\mathrm{NNC} 112$ and ${ }^{11} \mathrm{C}-\mathrm{MDL}$ 100907. Results: At $6 \mathrm{mo}$ of age, the $B P_{\mathrm{ND}}$ in the striatum was lower in ZQ175 than WT animals by $40 \%$ for ${ }^{11} \mathrm{C}$-raclopride, by $52 \%$ for ${ }^{18} \mathrm{~F}-\mathrm{MNI}-659$, by $28 \%$ for ${ }^{11} \mathrm{C}-\mathrm{NNC}$, and by $11 \%$ for ${ }^{11} \mathrm{C}-\mathrm{MDL}$ 100907. In the rostral cortex, $D_{1}$ receptor binding was $22 \%$ lower in zQ175 than WT animals. We found an overall reduction in $D_{1}$ and $5-\mathrm{HT}_{2 \mathrm{~A}}$ binding in the hippocampus of ZQ175 compared with WT animals. The $B P_{\mathrm{ND}}$ of ${ }^{11} \mathrm{C}-\mathrm{MDL} 100907$ in the caudal cortex was also lower in zQ175 WT animals. At $9 \mathrm{mo}$, there was a slight further reduction of $\mathrm{D}_{1}, \mathrm{D}_{2}$, and $5-\mathrm{HT}_{2 \mathrm{~A}} B P_{\mathrm{ND}}$ in the striatum, whereas PDE10A reached a plateau. Cortical markers were also slightly further decreased at 9 mo in zQ175 animals. Conclusion: Our study indicates a marked reduction of ligand binding to $\mathrm{D}_{1}$ and $\mathrm{D}_{2}$ and $5-\mathrm{HT}_{2 \mathrm{~A}}$ receptors as well as loss of PDE10A enzyme in the striatum of $z Q 175$ mice as compared with WT animals, in agreement with data obtained in clinical PET studies of patients with HD. The zQ175 mouse model recapitulates the expression pattern seen in humans with $\mathrm{HD}$ and may have value in further elucidating pathophysiologic events and therapeutic strategies.

Key Words: animal imaging; neurology; PET; PDEA10A enzyme; dopamine; serotonin

J Nucl Med 2017; 58:617-622

DOI: 10.2967/jnumed.116.180497

\footnotetext{
Received Aug. 1, 2016; revision accepted Oct. 21, 2016.

For correspondence or reprints contact: Jenny Häggkvist, Karolinska Institutet, Department of Clinical Neuroscience, R5:02, Karolinska University Hospital, Solna, SE-171 76 Stockholm, Sweden.

E-mail: Jenny.Haggkvist@ki.se

Published online Nov, 10, 2016.

COPYRIGHT @ 2017 by the Society of Nuclear Medicine and Molecular Imaging.
}

$\mathbf{H}$ untington disease (HD) is a neurodegenerative genetic disorder, characterized by progressive loss of medium spiny neurons in the striatum. The disease is caused by expansion of the CAGrepeat in exon 1 in the coding gene for the protein huntingtin (HTT) on chromosome 4 (1). To date, no disease-modifying therapies are available for HD. Developing novel effective therapies for HD will require a clearer understanding of the underlying disease pathophysiology. Several studies suggest that changes in the brain occur years before onset of disease symptoms, and abnormalities in the brain, mainly in the striatum, have been demonstrated even during the premanifest stage of the disease (2-4). Several neurotransmitter systems and enzymes have been suggested to be affected in HD such as the dopamine system (58 ), the phosphodiesterase 10 A (PDE10A) enzyme (9-11), and the serotonin system (12-14).

Since the discovery of the HTT gene in 1993, numerous genetically modified animal models for HD have been developed. A recently reported animal model for HD is the zQ175 knock-in model that shows motor, cognitive, molecular, and electrophysiologic abnormalities and decreased body weight $(15,16)$. The zQ175 animals, similar to HD patients, show altered messenger RNA expression levels in the striatum in genes such as $D_{2}$ receptor, PDE10A, the cannabinoid receptor-1, and dopamine-and cyclicAMP-regulated phosphoprotein (DARPP32) as well increased striatal atrophy and reduced cortical thickness (15-17).

To further characterize the zQ175 mouse model, we evaluated changes in neuroreceptor systems relevant for the progression of HD using small-animal PET in heterozygous zQ175 and wild-type (WT) mice. We imaged 6- and 9-mo-old heterozygous zQ175 and WT mice with radioligands specific for the $\mathrm{D}_{2} / \mathrm{D}_{3}$ receptor ${ }^{11} \mathrm{C}$ raclopride, PDE10A ${ }^{18} \mathrm{~F}-\mathrm{MNI}-659, \mathrm{D}_{1}$ receptor ${ }^{11} \mathrm{C}-\mathrm{NNC} 112$, and $5-\mathrm{HT}_{2 \mathrm{~A}}$ receptor ${ }^{11} \mathrm{C}-\mathrm{MDL} 100907$. The overall aim was to evaluate zQ175 mice as an animal model for HD and, more importantly, to find the most appropriate imaging biomarker to assess the efficacy of novel experimental therapies aimed at lowering mutant HTT.

\section{MATERIALS AND METHODS}

Animals

WT (C57BL/6J) and heterozygous zQ175 (Htt ${ }^{\text {tm1Mfc} / 190 J C h d i, ~}$ CHDI-81003003 (16)) male mice were obtained from The Jackson Laboratory. Genotyping and CAG repeat count were determined by Laragen Inc. Animals were housed in groups, and the experiments 
were performed in accordance with the guidelines of the Swedish National Board of Laboratory Animals under protocols approved by the Animal Ethics Review Board of Northern Stockholm, Sweden (N558/11). More information regarding the animals is provided in the supplemental materials (available at http://jnm.snmjournals.org).

\section{Radiosynthesis}

All radioligands were synthesized at Karolinska Institutet PET Centre. ${ }^{11} \mathrm{C}$-raclopride was synthesized as described earlier (18) by methylation of the desmethyl precursor analog using ${ }^{11} \mathrm{C}$-methyl triflate. The labeling yield was $50 \%-70 \%$, and the radiochemical purity was greater than $99 \%$. Synthesis of ${ }^{18} \mathrm{~F}-\mathrm{MNI}-659$ was accomplished by reacting ${ }^{18} \mathrm{~F}$-fluoride ion with the MNI-659 labeling precursor $(5-6 \mathrm{mg}$ [0.007-0,009 mmol] in dimethyl sulfoxide [600 $\mu \mathrm{L}]$ ), followed by purification and formulation into a solution containing propyleneglycol, ethanol, and phosphate-buffered saline solution as previously described (19). Radiochemical purity was greater than $98 \%$, and labeling yield was $10 \%-25 \%$. ${ }^{11} \mathrm{C}-\mathrm{NNC} 112$ was prepared by $\mathrm{N}$-methylation of the precursor using ${ }^{11} \mathrm{C}$-methyl triflate as previously described (20). The labeling yield was $70 \%-90 \%$, and the radiochemical purity was greater than $99 \%$. Finally, ${ }^{11} \mathrm{C}-\mathrm{MDL} 100907$ was labeled as described earlier (21) in its 3-methoxy position using ${ }^{11} \mathrm{C}$-methyl iodide as the labeling agent. The labeling yield was $60 \%-80 \%$, and the radiochemical purity was greater than $99 \%$.

\section{In Vivo PET Imaging}

All PET measurements were performed on the Mediso nanoScan PET/MRI and nanoScan PET/CT preclinical imaging systems $(22,23)$. The 2 systems have identical PET performance (22) and were calibrated to provide consistent results. Genotypes were divided equally between the 2 PET systems. On the experiment day, the animal was anesthetized with inhalation of $4 \%-5 \%$ of isoflurane. After induction of anesthesia, the isoflurane concentration was lowered to $1.5 \%-2 \%$, and the animal was positioned in the scanner. A 63 -min $\left({ }^{11} \mathrm{C}\right.$-raclopride and $\left.{ }^{18} \mathrm{~F}-\mathrm{MNI}-659\right)$ or $93-\mathrm{min}\left({ }^{11} \mathrm{C}-\mathrm{NNC} 112\right.$ and $\left.{ }^{11} \mathrm{C}-\mathrm{MDL} 100907\right)$ dynamic PET measurement was initiated immediately on intravenous injection of the radioligand. Data on the weight of the animals, injected radioactivity levels, and injected mass for each radioligand at each time point are displayed in Supplemental Table 1. Each animal was imaged twice, with 2 different radioligands at 6 and 9 mo of age. The animals were imaged in the same PET system at both time points.

\section{Image and Statistical Analysis}

The image data files were reconstructed with a maximum-likelihood expectation maximization algorithm (20 iterations) and a $0.3 \times 0.3 \times$ $0.3 \mathrm{~mm}$ voxel size. The individual PET images were manually coregistered to the inbuilt MRI mouse template using PMOD software (version 3.4; PMOD Technologies). All the related image data analysis was performed with PMOD. For delineation of the regions of interest (ROIs), we used the inbuilt ROI template for the mouse available in PMOD. The ROI template for the cortex was modified to separate the rostral and caudal part at approximately Bregma $-3 \mathrm{~mm}$ (Supplemental Fig. 1). The division was chosen to have a more caudal part of the cortex, which would be less prone to spill-in from the high-activity striatal region due to partial-volume effects. The main outcome measure was binding potential $\left(B P_{\mathrm{ND}}\right) . B P_{\mathrm{ND}}$ was calculated in the striatum for ${ }^{11} \mathrm{C}$-raclopride and ${ }^{18} \mathrm{~F}-\mathrm{MNI}-659$ and in the striatum, rostral cortex, caudal cortex, and hippocampus for ${ }^{11} \mathrm{C}-\mathrm{MDL} 100907$ using the simplified reference tissue model (24). For ${ }^{11} \mathrm{C}-\mathrm{NNC} 112$, the $B P_{\mathrm{ND}}$ was calculated in the striatum, rostral cortex, caudal cortex, and hippocampus using the noninvasive version of the Logan linear graphic method (25) because the simplified reference tissue model proved to be unreliable to estimate $B P_{\mathrm{ND}}$ due to slow kinetics in the striatum. In the Logan linear graphic method, a linear phase was obtained from $33 \mathrm{~min}$ for the striatum and cortical regions. This method yielded reliable estimates of $B P_{\mathrm{ND}}$ for all regions studied. For all radioligands, the $B P_{\mathrm{ND}}$ was calculated using the cerebellum as the reference region. The difference between WT and zQ175 was analyzed with repeated-measures ANOVA (with strain and age as factors) using SPSS Statistics for Windows (version 22.0; IBM). If the repeated-measures ANOVA showed a statistically significant difference between $\mathrm{zQ} 175$ and WT, a $t$ test was run at 6 and 9 mo, respectively, to investigate the difference at each time point. Only those animals that were imaged during both time points ( 6 and 9 mo of age) were included in the repeated-measures ANOVA.

\section{RESULTS}

\section{Imaging Dopamine $D_{2} / D_{3}$ System Using ${ }^{11} C$-Raclopride}

The average \%SUV images, obtained with ${ }^{11} \mathrm{C}$-raclopride, showed lower $\mathrm{D}_{2} / \mathrm{D}_{3}$ receptor binding in $\mathrm{zQ} 175$ mice than in WT animals at 6 and 9 mo (Fig. 1A). A repeated-measures ANOVA showed a statistically significant difference in the $B P_{\mathrm{ND}}$ between the WT and $z Q 175$ mice $\left(F_{1,26}=305.7 ; P<0.001\right.$, Fig. 1B). The difference in $B P_{\mathrm{ND}}$ of ${ }^{11} \mathrm{C}$-raclopride was $40 \%$ at 6 mo of age and $44 \%$ at 9 mo of age. There was an age-related reduction in raclopride binding $\left(F_{1,26}=37.29 ; P<0.001\right)$, an effect independent of strain $\left(F_{1,26}=0.16 ; P>0.05\right)$. At $9 \mathrm{mo}$, the $B P_{\mathrm{ND}}$ in the WT was $11 \%$ lower than at $6 \mathrm{mo}$, and in the zQ175 this difference was $16 \%$ (Fig. 1B). Average $B P_{\mathrm{ND}}$ values for 6 and 9 mo in both WT and zQ175 are shown in Supplemental Table 2.

\section{Imaging PDE10A Enzyme Using ${ }^{18} \mathrm{~F}-\mathrm{MNI}-659$}

Average \%SUV images of ${ }^{18} \mathrm{~F}-\mathrm{MNI}-659$ are displayed in Figure 2A (6- and 9-mo-old WT and zQ175 mice). Repeated-measure ANOVA showed a statistically significant difference between the WT and zQ175 mice $\left(F_{1,26}=26.62 ; P<0.001\right.$, Fig. $\left.2 \mathrm{~B}\right)$. The difference of ${ }^{18} \mathrm{~F}-\mathrm{MNI}-659 B P_{\mathrm{ND}}$ between $\mathrm{zQ} 175$ and WT animals was $52 \%$ at 6 mo of age and $41 \%$ at 9 mo of age. There was no statistically significant change in ${ }^{18} \mathrm{~F}-\mathrm{MNI}-659$ binding between the 2 time points $\left(F_{1,26}=0.18 ; P>0.05\right)$, an effect observed in both strains $\left(F_{1,26}=1.39 ; P>0.05\right.$, Fig. $\left.2 \mathrm{~B}\right)$. Average $B P_{\mathrm{ND}}$ values for 6 and 9 mo in both WT and zQ175 are shown in Supplemental Table 2 .

\section{Imaging $D_{1}$ Receptors Using ${ }^{11} \mathrm{C}-\mathrm{NNC} \mathbf{1 1 2}$}

Average \%SUV images, obtained with ${ }^{11} \mathrm{C}-\mathrm{NNC} 112$, are displayed in Figure 3A. Repeated-measures ANOVA was performed, and at 6 mo of age there was a $28 \%$ difference in $B P_{\mathrm{ND}}$ in the striatum between WT and zQ175, and at 9 mo of age the difference had increased to $34 \%\left(F_{1,26}=19.71 ; P<0.001\right.$, Fig. 3B). In the rostral cortex, at 6 mo of age, a $22 \%$ lower $B P_{\mathrm{ND}}$ was found in the $\mathrm{zQ} 175$ as compared with WT animals, and at 9 mo the difference between the 2 strains was $23 \%$ $\left(F_{1,26}=22.43 ; P<0.001\right.$, Fig. 3B $)$. Also in the hippocampus, a statistically significant difference between zQ175 and WT was found $\left(F_{1,26}=5.27 ; P<0.05\right)$. The $t$ test at each time point showed a statistically significant difference between the 2 strains at 9 mo $(P<0.05)$ but not at 6 mo $(P>0.05)$. There was no statistically significant difference between WT and zQ175 in the caudal cortex $\left(F_{1,26}=2.19 ; P>0.05\right)$. We observed a significant decrease in ${ }^{11} \mathrm{C}$-NNC 112 binding between the 2 time points in the rostral cortex $\left(F_{1,26}=29.07\right.$; $P<0.001)$, caudal cortex $\left(F_{1,26}=30.51 ; P<0.001\right)$, and hippocampus $\left(F_{1,26}=13.74 ; P<0.001\right)$, an effect independent of strain (rostral cortex: $F_{1,26}=0.35, P>0.05$; caudal cortex: $F_{1,26}=$ $1.01, P>0.05$; hippocampus: $F_{1,26}=2.21, P>0.05$; Fig. 3B). Mean values of $B P_{\mathrm{ND}}$ in the striatum, rostral cortex, 


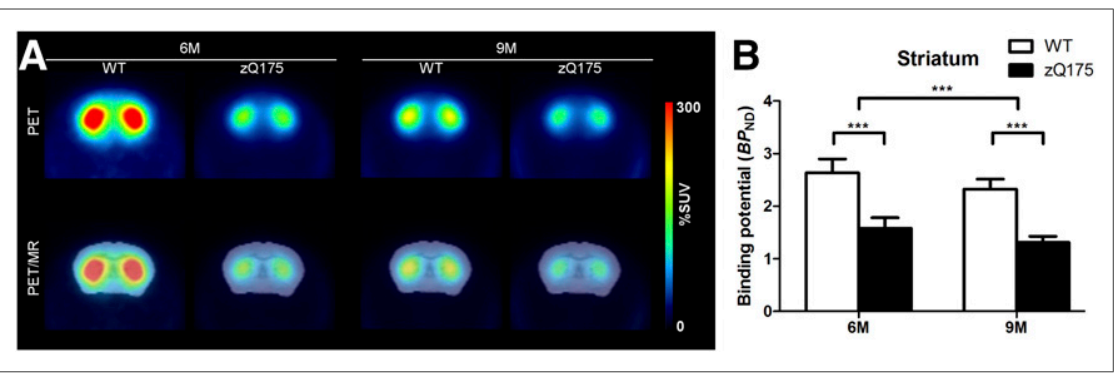

FIGURE 1. (A) Average ${ }^{11} \mathrm{C}$-raclopride $\left(D_{2} / D_{3}\right.$ receptor radioligand) \%SUV images of 6 - and 9 -moold WT and zQ175 mice. PET measurement averaged from 15 to $63 \mathrm{~min}$ is shown in top row, and coregistered PET to template MR image is shown in bottom row. (B) $B P_{\mathrm{ND}}{ }^{\circ}{ }^{11} \mathrm{C}$-raclopride in striatum is shown. Values are expressed as mean $\pm \mathrm{SD}$. ${ }^{* \star} P<0.001, n=14$ /group. $\mathrm{M}=$ mo.

by investigating whether the changes in the brain could be used either as potential translational biomarkers for disease progression studies or to evaluate the effect of HTT-lowering therapeutic agents or other disease-modification treatments. In the striatum, the $\mathrm{zQ} 175$ animals showed lower $B P_{\mathrm{ND}}$ with all radioligands used in the present study. In extrastriatal regions, the zQ175 mice had a lower $\mathrm{D}_{1}$ receptor binding in the rostral cortex and hippocampus as well as lower $5-\mathrm{HT}_{2 \mathrm{~A}}$ binding in the caudal cortex and hippocampus. These results suggest that the animals showed alterations in the

caudal cortex, and hippocampus are shown in Supplemental Table 2.

\section{Imaging 5-HT ${ }_{2 \mathrm{~A}}$ Receptors Using ${ }^{11} \mathrm{C}-\mathrm{MDL} 100907$}

Average \%SUV images, obtained with ${ }^{11} \mathrm{C}-\mathrm{MDL} 100907$, are displayed in Figure 4A. Repeated-measures ANOVA showed statistically significant differences between WT and zQ175 in the striatum $\left(F_{1,24}=10.82 ; P<0.001\right)$, caudal cortex $\left(F_{1,24}=6.04\right.$; $P<0.05)$, and hippocampus $\left(F_{1,24}=10.85 ; P<0.001\right.$; Fig. $\left.4 \mathrm{~B}\right)$. The $B P_{\mathrm{ND}}$ in the striatum of zQ175 animals was $11 \%$ lower than that in WT at 6 mo of age and $20 \%$ lower at 9 mo of age. In the caudal cortex, the difference between the 2 strains was $9 \%$ at $6 \mathrm{mo}$ and $18 \%$ at 9 mo. Finally, in the hippocampus, the zQ175 mice displayed a $15 \%$ lower $B P_{\mathrm{ND}}$ at 6 mo than the WT mice, and the difference between the 2 groups was $20 \%$ at 9 mo. There was an overall statistically significant decrease in the $B P_{\mathrm{ND}}$ of ${ }^{11} \mathrm{C}$-MDL 100907 at 9 mo compared with 6 mo in all regions examined (striatum: $F_{1,24}=62.8, P<0.001$; rostral cortex: $F_{1,24}=42.67, P<0.001$; caudal cortex: $F_{1,24}=55.09, P<$ 0.001 ; and hippocampus: $F_{1,24}=48.84, P<0.001$ ). This decrease was seen in both WT and zQ175 animals, with no statistically significant interaction effect (striatum: $F_{1,24}=2.951, P>$ 0.05; rostral cortex: $F_{1,24}=0.071, P>0.05$; caudal cortex: $F_{1,24}=$ 1.782, $P>0.05$; and hippocampus: $F_{1,24}=0.0089, P>0.05$; Fig, $4 \mathrm{~B})$. Mean values of $B P_{\mathrm{ND}}$ in the striatum, rostral cortex, caudal cortex, and hippocampus are shown in Supplemental Table 2.

\section{DISCUSSION}

We used in vivo small-animal PET imaging to further characterize the $\mathrm{zQ} 175$ heterozygous mouse as a model for HD
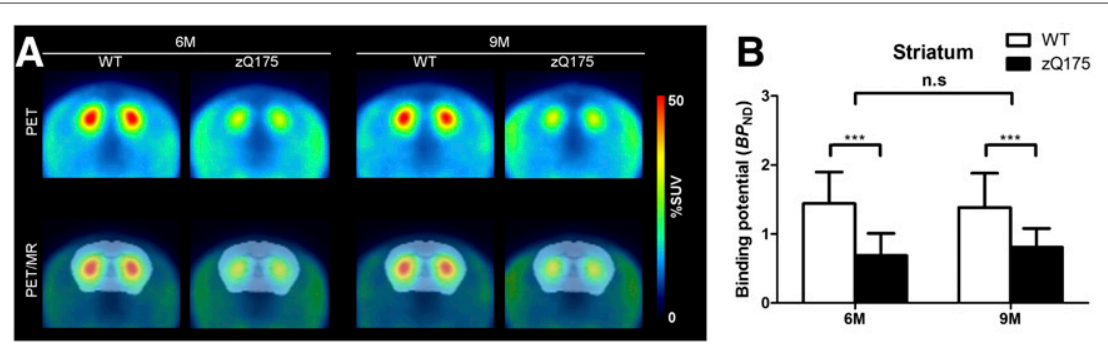

FIGURE 2. (A) Average ${ }^{18} \mathrm{~F}-\mathrm{MNI}-659$ (PDE10A enzyme radioligand) \%SUV images of 6- and 9-mo-old WT and $z Q 175$ mice. PET measurement averaged from 15 to $63 \mathrm{~min}$ is shown in top row, and coregistered PET to template MR image is shown in bottom row. (B) $B P_{\mathrm{ND}}$ of ${ }^{18} \mathrm{~F}-\mathrm{MNN}-659$ in striatum at 6 and 9 mo of age is shown. Values are expressed as mean $\pm \mathrm{SD} .{ }^{\star \star} P<0.001, n=14 /$ group. $\mathrm{M}=\mathrm{mo}$; n.s. $=$ not significant.
$\mathrm{D}_{1}, \mathrm{D}_{2}$, and $5-\mathrm{HT}_{2 \mathrm{~A}}$ receptor systems as well as lower levels of PDE10 enzyme, all in accordance with findings in patients $(6,7,9,11,13,26)$.

\section{Dopamine $D_{1}$ and $D_{2}$ Receptors}

The observed loss of $D_{1}$ and $D_{2}$ receptor availability in the striatum of $z Q 175$ mice is in line with the results previously reported in HD patients $(5-8,27)$. The reduced availability of the $\mathrm{D}_{1}$ and $\mathrm{D}_{2}$ receptors is correlated with increasing illness duration (6) and worse cognitive performance (27). Changes in the $\mathrm{D}_{1}$ and $\mathrm{D}_{2}$ receptors have also been observed during the premanifest phase of the disease in HD gene carriers $(2,8)$, correlating both with cognitive performance (28) and with Unified Huntington's Disease Rating Scale motor scores (29).

The dopamine $D_{1}$ receptors are also highly expressed in other brain regions, such as the cortex and hippocampus (3032). We found that $z Q 175$ mice had lower $D_{1}$ receptor binding in the rostral cortex and hippocampus than WT animals. Reduction of cortical $\mathrm{D}_{1}$ receptor availability has also been reported in HD patients (6), suggesting that the $\mathrm{D}_{1}$ receptor could be a useful translational imaging marker for extrastriatal areas in $\mathrm{zQ} 175$ mice.

One limitation of using ${ }^{11} \mathrm{C}-\mathrm{NNC} 112$ for imaging of the $\mathrm{D}_{1}$ receptors is that it binds both dopamine $\mathrm{D}_{1}$ receptors and serotonin $5-\mathrm{HT}_{2 \mathrm{~A}}$ receptors in the cortex $(33,34) .{ }^{11} \mathrm{C}-\mathrm{NNC} 112$ has a 5- to 10 -fold selectivity for $\mathrm{D}_{1}$ over $5-\mathrm{HT}_{2 \mathrm{~A}}$ in vivo; however, because the density of the $5-\mathrm{HT}_{2 \mathrm{~A}}$ is about twice that of $\mathrm{D}_{1}$ receptors in the cortex (35), part of the $B P_{\mathrm{ND}}$ of ${ }^{11} \mathrm{C}-\mathrm{NNC} 112$ in the cortex could stem from $5-\mathrm{HT}_{2 \mathrm{~A}}$ receptor binding. Care should therefore be taken in the interpretation of the results from ${ }^{11} \mathrm{C}-\mathrm{NNC} 112$ in cortical areas.

We found a reduction in $D_{1}$ and $D_{2}$ dopamine receptor availability with age in both WT and zQ175 mice. There was no statistically significant difference between the 2 strains in age-related decline of $B P_{\mathrm{ND}}$ of either ${ }^{11} \mathrm{C}$-raclopride or ${ }^{11} \mathrm{C}$ NNC 112. An age-related decrease of $\mathrm{D}_{1}$ and $\mathrm{D}_{2}$ receptors is also seen in humans (36-39), with an approximate decline of $4 \%-9 \%$ per decade. Whether the agerelated decline is more profound in HD patients than in healthy individuals is not clear; a 2-y follow-up study did not find a significantly higher rate of decline in the $B P_{\mathrm{ND}}$ of ${ }^{11} \mathrm{C}$-raclopride in presymptomatic 


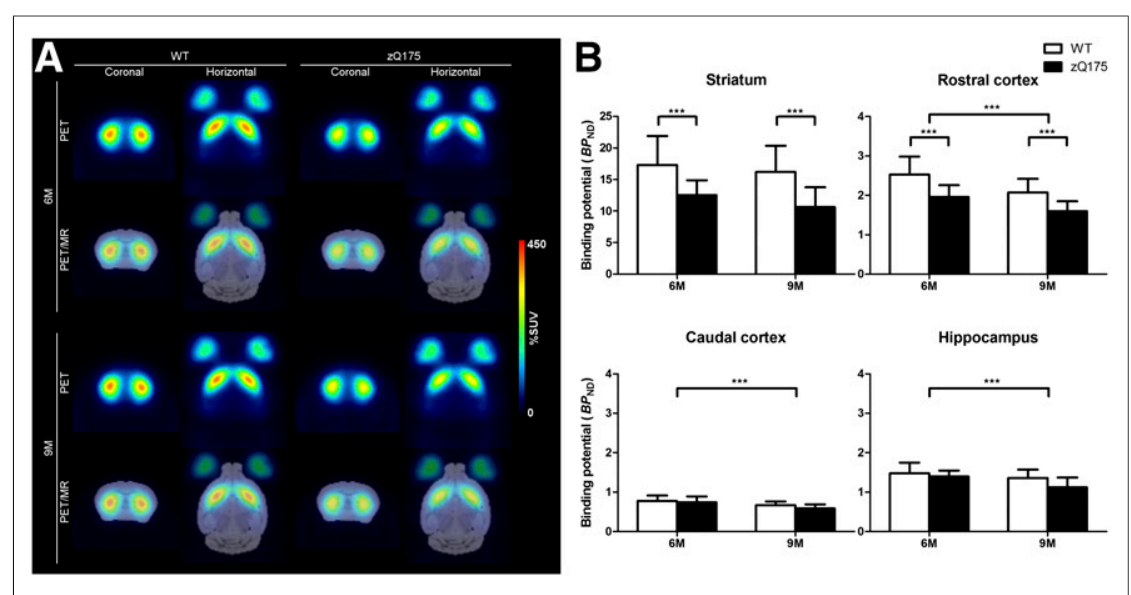

FIGURE 3. (A) Average ${ }^{11} \mathrm{C}-\mathrm{NNC} 112\left(\mathrm{D}_{1}\right.$ receptor radioligand) \%SUV images of 6- and 9-moold WT and zQ175 mice. PET measurement averaged from 36 to 93 min is shown (rows 1 and 3), and coregistered PET to template MR image is also shown (rows 2 and 4). (B) $B P_{\mathrm{ND}}$ of ${ }^{11} \mathrm{C}-\mathrm{NNC}$ 112 in striatum, rostral cortex, caudal cortex, and hippocampus in 6- and 9-mo-old WT and $z$ Q175 mice is shown. Values are expressed as mean \pm SD. ${ }^{* \star *} P<0.001$. WT, $n=15$; $\mathrm{zQ175}, n=13 . \mathrm{M}=\mathrm{mo}$.

HD gene carriers $(2.6 \%$ decline per year) than controls $(1.8 \%$ decline per year) (40), a result in accordance with our findings in the zQ175 mice. However, manifest HD patients have been reported to show a progressive loss of $\mathrm{D}_{2}$ receptors, with an average decline of $5 \%$ per year $(41)$.

\section{Role of PDE10A}

In the current study, we found a decrease in the $B P_{\mathrm{ND}}$ of ${ }^{18} \mathrm{~F}-\mathrm{MNI}-659$ in the zQ175 mice compared with WT mice at both 6 and 9 mo of age. This is in line with recent human PET studies reporting a $50 \%$ reduction of binding of the PDE10A enzyme in the striatum of HD patients compared with controls $(9,11)$. Additionally, a $70 \%-80 \%$ reduction in PDE10A $B P_{\mathrm{ND}}$ by $12 \mathrm{wk}$ of age in the R6/2 HD mouse model compared with WT has been reported using another PET radioligand for PDE10A, ${ }^{18}$ F-JNJ42259152 (42).

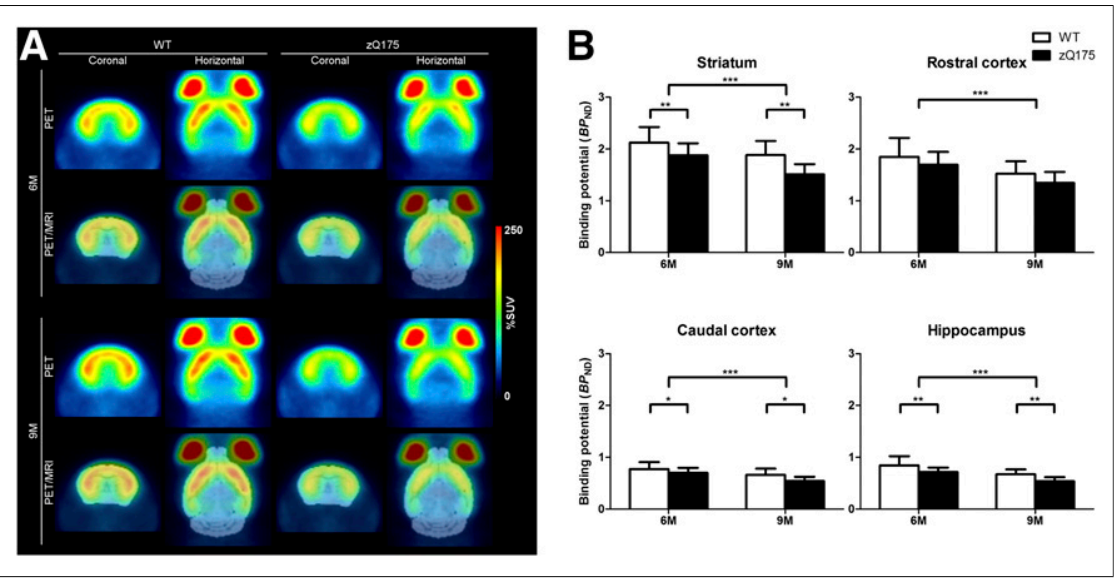

FIGURE 4. (A) Average ${ }^{11} \mathrm{C}-\mathrm{MDL} 100907\left(5-\mathrm{HT}_{2 \mathrm{~A}}\right.$ receptor radioligand) \%SUV images of 6- and 9-mo-old WT and zQ175 mice. PET measurement averaged from 36 to 93 min is shown (rows 1 and 3), and coregistered PET to template MR image is also shown (rows 2 and 4). (B) $B P_{\mathrm{ND}}$ of ${ }^{11} \mathrm{C}-\mathrm{MDL} 100907$ in striatum, rostral cortex, caudal cortex, and hippocampus in 6 - and 9-mo-old WT and zQ175 mice is shown. Values are expressed as mean \pm SD. ${ }^{\star} P<0.05 .{ }^{\star \star} P<0.01 .{ }^{* \star \star} P<0.001$. WT, $n=14 ; \mathrm{zQ175}, n=12 . \mathrm{M}=\mathrm{mo}$.
In the zQ175 mice, we found no further decrease in $B P_{\mathrm{ND}}$ of ${ }^{18} \mathrm{~F}-\mathrm{MNI}-659$ at 9 mo compared with 6 mo, suggesting a plateau. These results agree with the previously reported $50 \%$ reduction in PDE10A messenger RNA levels in the zQ175 mice at $18 \mathrm{wk}$ of age as compared with WT animals, with no further decrease at 41 wk of age (16). To our knowledge, there are no published data regarding the effect of aging on PDE10A in humans, but unpublished data from our research groups suggest that there is a significant negative correlation between age and $B P_{\mathrm{ND}}$ of ${ }^{18} \mathrm{~F}$ MNI-659. However, these age-related changes are only significant when an age span of almost $40 \mathrm{y}$ is included. In the present study, we used 6- and 9-mo-old mice, and the lack of age effect in both zQ175 and WT animals may be due to their relatively young age and the short interval between the 2 PET measurements.

\section{Serotonin 5-HT $2 \mathrm{~A}$ Receptors}

Cortical pathology is also evident in HD (43). To evaluate a potential imaging target for the cortex, we used ${ }^{11} \mathrm{C}-\mathrm{MDL}$ 100907, a PET radioligand developed for imaging the $5-\mathrm{HT}_{2 \mathrm{~A}}$ receptor $(21,44)$. Postmortem autoradiography studies have shown reduced serotonin receptor binding in HD brains $(12,13,26,45)$. In the present study, we found a statistically significant reduction of $5-\mathrm{HT}_{2 \mathrm{~A}}$ binding in the striatum, caudal cortex, and hippocampus in zQ175 mice as compared with WT animals. The difference between the 2 strains was evident already at 6 mo, with a $9 \%-15 \%$ lower $B P_{\mathrm{ND}}$ in $\mathrm{zQ} 175$ mice, an effect that increased to almost $20 \%$ at 9 mo of age.

The highest density of the $5-\mathrm{HT}_{2 \mathrm{~A}}$ receptors in the rodent brain is within lamina $\mathrm{V}$ of the cortex and in the claustrum. Additional regions enriched with receptors are the olfactory system, caudate-putamen, nucleus accumbens, and hippocampus $(46,47)$. One challenge when performing small-animal PET imaging, with special regards to the accuracy of quantification, is the resolution of PET. We used the high-resolution nanoScan PET/MR and PET/CT systems (22,23). The mouse cortex is about $1.2 \mathrm{~mm}$ thick, which is comparable to the full width at half maximum of the system. We found similar $B P_{\mathrm{ND}}$ in the striatum and rostral cortex. An autoradiographic study with ${ }^{3} \mathrm{H}-\mathrm{MDL} 100907$ showed a heterogeneous distribution of the $5-\mathrm{HT}_{2 \mathrm{~A}}$ in the caudate-putamen, with a higher density in the more posterior parts (Supplemental Fig. 2). We used the ROI template available in PMOD for delineation of the ROIs, in which the caudateputamen and nucleus accumbens are merged into 1 region, that is, the striatum. Because of the close proximity of the striatum to the claustrum and also to the lamina V of the cortex (Supplemental 
Fig. 3), the activity in the striatum could be influenced by partialvolume effect from these 2 regions, leading to a possible overestimation of $B P_{\mathrm{ND}}$. Despite a possible bias in the estimation of $B P_{\mathrm{ND}}$ in the striatum, a similar effect had probably occurred in both strains of the mice, most likely without affecting the differences between WT and zQ175 animals.

\section{CONCLUSION}

We show here that $\mathrm{zQ} 175$ mice have altered brain biochemistry, that is, reduced availability of the $\mathrm{D}_{1}, \mathrm{D}_{2}$, and $5-\mathrm{HT}_{2 \mathrm{~A}}$ receptors, as well as reduced binding to the PDE10A enzyme, in accordance with findings in HD patients. Our study, together with previous behavioral and neurophysiologic studies on the zQ175 mouse model $(15,16)$, supports the utility of using zQ175 mice as an animal model in HD research. In addition, ${ }^{11} \mathrm{C}$-raclopride, ${ }^{18} \mathrm{~F}-\mathrm{MNI}-659,{ }^{11} \mathrm{C}-\mathrm{NNC} 112$, and ${ }^{11} \mathrm{C}-\mathrm{MDL}$ 100907 are all potential imaging biomarkers to monitor the neurochemical effects of novel experimental therapies in this HD animal model.

\section{DISCLOSURE}

This work was supported by the CHDI Foundation. No other potential conflict of interest relevant to this article was reported.

\section{ACKNOWLEDGMENTS}

Precursor material for ${ }^{18} \mathrm{~F}-\mathrm{MNI}-659$ was kindly provided by MNI (Molecular NeuroImaging New Haven). We would also like to express our gratitude to members of the Karolinska PET group for their participation during the PET imaging as well as to the CHDI Foundation for supporting this work.

\section{REFERENCES}

1. MacDonald ME, Ambrose CM, Duyao MP, et al. A novel gene containing a trinucleotide repeat that is expanded and unstable on Huntington's disease chromosomes. The Huntington's Disease Collaborative Research Group. Cell. 1993;72:971-983.

2. Antonini A, Leenders KL, Eidelberg D. $\left[{ }^{11} \mathrm{C}\right]$ raclopride-PET studies of the Huntington's disease rate of progression: relevance of the trinucleotide repeat length. Ann Neurol. 1998;43:253-255.

3. Grafton ST, Mazziotta JC, Pahl JJ, et al. Serial changes of cerebral glucose metabolism and caudate size in persons at risk for Huntington's disease. Arch Neurol. 1992;49:1161-1167.

4. Mazziotta JC, Phelps ME, Pahl JJ, et al. Reduced cerebral glucose metabolism in asymptomatic subjects at risk for Huntington's disease. N Engl J Med. 1987;316: $357-362$.

5. Esmaeilzadeh $M$, Farde L, Karlsson $P$, et al. Extrastriatal dopamine $\mathrm{D}_{2}$ receptor binding in Huntington's disease. Hum Brain Mapp. 2011;32: 1626-1636.

6. Ginovart N, Lundin A, Farde L, et al. PET study of the pre- and post-synaptic dopaminergic markers for the neurodegenerative process in Huntington's disease. Brain. 1997;120:503-514.

7. Turjanski N, Weeks R, Dolan R, Harding AE, Brooks DJ. Striatal D1 and D2 receptor binding in patients with Huntington's disease and other choreas. A PET study. Brain. 1995;118:689-696.

8. Weeks RA, Piccini P, Harding AE, Brooks DJ. Striatal D1 and D2 dopamine receptor loss in asymptomatic mutation carriers of Huntington's disease. Ann Neurol. 1996;40:49-54.

9. Ahmad R, Bourgeois S, Postnov A, et al. PET imaging shows loss of striatal PDE10A in patients with Huntington disease. Neurology. 2014;82:279-281.
10. Hebb AL, Robertson HA, Denovan-Wright EM. Striatal phosphodiesterase mRNA and protein levels are reduced in Huntington's disease transgenic mice prior to the onset of motor symptoms. Neuroscience. 2004;123: 967-981.

11. Russell DS, Barret O, Jennings DL, et al. The phosphodiesterase 10 positron emission tomography tracer, $\left[{ }^{18} \mathrm{~F}\right] \mathrm{MNI}-659$, as a novel biomarker for early Huntington disease. JAMA Neurol. 2014;71:1520-1528.

12. Castro ME, Pascual J, Romon T, Berciano J, Figols J, Pazos A. 5-HT1B receptor binding in degenerative movement disorders. Brain Res. 1998;790: $323-328$.

13. Waeber C, Palacios JM. Serotonin-1 receptor binding sites in the human basal ganglia are decreased in Huntington's chorea but not in Parkinson's disease: a quantitative in vitro autoradiography study. Neuroscience. 1989;32:337347.

14. Yohrling GJ, Jiang GCT, DeJohn MM, Robertson DJ, Vrana KE, Cha JHJ. Inhibition of tryptophan hydroxylase activity and decreased 5-HT1A receptor binding in a mouse model of Huntington's disease. J Neurochem. 2002;82:1416-1423.

15. Heikkinen T, Lehtimaki K, Vartiainen N, et al. Characterization of neurophysiological and behavioral changes, MRI brain volumetry and ${ }^{1} \mathrm{H}$ MRS in zQ175 knock-in mouse model of Huntington's disease. PLoS One. 2012;7: e50717.

16. Menalled LB, Kudwa AE, Miller S, et al. Comprehensive behavioral and molecular characterization of a new knock-in mouse model of Huntington's disease: zQ175. PLoS One. 2012;7:e49838.

17. Smith GA, Rocha EM, McLean JR, et al. Progressive axonal transport and synaptic protein changes correlate with behavioral and neuropathological abnormalities in the heterozygous Q175 KI mouse model of Huntington's disease. Hum Mol Genet. 2014;23:4510-4527.

18. Langer O, Nagren K, Dolle F, et al. Precursor synthesis and radiolabelling of the dopamine D-2 receptor ligand [C-11]raclopride from [C-11]methyl triflate. $J$ Labelled Comp Radiopharm. 1999;42:1183-1193.

19. Barret O, Thomae D, Tavares A, et al. In vivo assessment and dosimetry of 2 novel PDE10A PET radiotracers in humans: ${ }^{18} \mathrm{~F}-\mathrm{MNI}-659$ and ${ }^{18} \mathrm{~F}-\mathrm{MNI}-654 . \mathrm{J} \mathrm{Nucl}$ Med. 2014;55:1297-1304.

20. Halldin C, Foged C, Chou YH, et al. Carbon-11-NNC 112: a radioligand for PET examination of striatal and neocortical D1-dopamine receptors. J Nucl Med. 1998;39: 2061-2068.

21. Lundkvist C, Halldin C, Ginovart N, et al. [11C]MDL 100907, a radioligland for selective imaging of $5-\mathrm{HT}_{2 \mathrm{~A}}$ receptors with positron emission tomography. Life Sci. 1996;58:PL 187-192.

22. Nagy K, Toth M, Major P, et al. Performance evaluation of the small-animal nanoScan PET/MRI system. J Nucl Med. 2013;54:1825-1832.

23. Szanda I, Mackewn J, Patay G, et al. National Electrical Manufacturers Association NU-4 performance evaluation of the PET component of the NanoPET/CT preclinical PET/CT scanner. J Nucl Med. 2011;52: 1741-1747.

24. Lammertsma AA, Hume SP. Simplified reference tissue model for PET receptor studies. Neuroimage. 1996;4:153-158.

25. Logan J, Fowler JS, Volkow ND, Wang GJ, Ding YS, Alexoff DL. Distribution volume ratios without blood sampling from graphical analysis of PET data. $J$ Cereb Blood Flow Metab. 1996;16:834-840.

26. Steward LJ, Bufton KE, Hopkins PC, Davies WE, Barnes NM. Reduced levels of 5-HT3 receptor recognition sites in the putamen of patients with Huntington's disease. Eur J Pharmacol. 1993;242:137-143.

27. Bäckman L, Robins-Wahlin TB, Lundin A, Ginovart N, Farde L. Cognitive deficits in Huntington's disease are predicted by dopaminergic PET markers and brain volumes. Brain. 1997;120:2207-2217.

28. Lawrence AD, Weeks RA, Brooks DJ, et al. The relationship between striatal dopamine receptor binding and cognitive performance in Huntington's disease. Brain. 1998;121:1343-1355.

29. Andrews TC, Weeks RA, Turjanski N, et al. Huntington's disease progression. PET and clinical observations. Brain. 1999;122:2353-2363.

30. Andersen PH, Gronvald FC. Specific binding of ${ }^{3} \mathrm{H}-\mathrm{SCH} 23390$ to dopamine D1 receptors in vivo. Life Sci. 1986;38:1507-1514.

31. Dawson TM, Gehlert DR, McCabe RT, Barnett A, Wamsley JK. D-1 dopamine receptors in the rat brain: a quantitative autoradiographic analysis. $J$ Neurosci. 1986;6:2352-2365.

32. Dubois A, Savasta M, Curet O, Scatton B. Autoradiographic distribution of the D1 agonist $\left[{ }^{3} \mathrm{H}\right] \mathrm{SKF} 38393$, in the rat brain and spinal cord: comparison with the distribution of D2 dopamine receptors. Neuroscience. 1986;19: 125-137.

33. Ekelund J, Slifstein $M$, Narendran R, et al. In vivo DA $D_{1}$ receptor selectivity of NNC 112 and SCH 23390. Mol Imaging Biol. 2007;9:117-125. 
34. Slifstein M, Kegeles LS, Gonzales R, et al. $\left[{ }^{11} \mathrm{C}\right] \mathrm{NNC} 112$ selectivity for dopamine D1 and serotonin 5- $\mathrm{HT}_{2 \mathrm{~A}}$ receptors: a PET study in healthy human subjects. J Cereb Blood Flow Metab. 2007;27:1733-1741.

35. Lidow MS, Goldman-Rakic PS, Gallager DW, Geschwind DH, Rakic P. Distribution of major neurotransmitter receptors in the motor and somatosensory cortex of the rhesus monkey. Neuroscience. 1989;32:609-627.

36. Antonini A, Leenders KL, Reist H, Thomann R, Beer HF, Locher J. Effect of age on D2 dopamine receptors in normal human brain measured by positron emission tomography and ${ }^{11}$ C-raclopride. Arch Neurol. 1993;50:474-480.

37. Jucaite A, Forssberg H, Karlsson P, Halldin C, Farde L. Age-related reduction in dopamine D1 receptors in the human brain: from late childhood to adulthood, a positron emission tomography study. Neuroscience. 2010;167:104-110.

38. Rinne JO, Hietala J, Ruotsalainen U, et al. Decrease in human striatal dopamine D2 receptor density with age: a PET study with $\left[{ }^{11} \mathrm{C}\right]$ raclopride. J Cereb Blood Flow Metab. 1993;13:310-314.

39. Wang Y, Chan GL, Holden JE, et al. Age-dependent decline of dopamine D1 receptors in human brain: a PET study. Synapse. 1998;30:56-61.

40. van Oostrom JC, Dekker M, Willemsen AT, de Jong BM, Roos RA, Leenders KL. Changes in striatal dopamine D2 receptor binding in pre-clinical Huntington's disease. Eur J Neurol. 2009;16:226-231.
41. Pavese N, Andrews TC, Brooks DJ, et al. Progressive striatal and cortical dopamine receptor dysfunction in Huntington's disease: a PET study. Brain. 2003;126:1127-1135.

42. Ooms M, Rietjens R, Rangarajan JR, et al. Early decrease of type 1 cannabinoid receptor binding and phosphodiesterase 10A activity in vivo in R6/2 Huntington mice. Neurobiol Aging. 2014;35:2858-2869.

43. de la Monte SM, Vonsattel JP, Richardson EP Jr. Morphometric demonstration of atrophic changes in the cerebral cortex, white matter, and neostriatum in Huntington's disease. J Neuropathol Exp Neurol. 1988;47:516-525.

44. Ito H, Nyberg S, Halldin C, Lundkvist C, Farde L. PET imaging of central 5-HT ${ }_{2 \mathrm{~A}}$ receptors with carbon-11-MDL 100,907. J Nucl Med. 1998;39:208-214.

45. Wong EH, Reynolds GP, Bonhaus DW, Hsu S, Eglen RM. Characterization of $\left[{ }^{3} \mathrm{H}\right]$ GR 113808 binding to 5-HT4 receptors in brain tissues from patients with neurodegenerative disorders. Behav Brain Res. 1996;73:249-252.

46. López-Giménez JF, Mengod G, Palacios JM, Vilaro MT. Selective visualization of rat brain 5-HT2A receptors by autoradiography with $\left[{ }^{3} \mathrm{H}\right] \mathrm{MDL} 100,907$. Naunyn Schmiedebergs Arch Pharmacol. 1997;356:446-454.

47. Weber ET, Andrade R. Htr2a gene and $5-\mathrm{HT}_{2 \mathrm{~A}}$ receptor expression in the cerebral cortex studied using genetically modified mice. Front Neurosci. $2010 ; 4$. 